\title{
Commitment and Pro-Environmental Behaviors: Favoring Positive Human-Environment Interactions to Improve Quality of Life
}

\author{
Christophe Demarque and Fabien Girandola
}

\subsection{Introduction}

Environmental psychology focuses on peopleenvironment relations. These relations are often considered in adaptative terms: how can one avoid degradations, limit the overexploitation of natural resources, or cope with some urban annoyances (noise, pollution, etc.)? From a different perspective, Weiss and Girandola (2009, 2010a, b) suggested developing a positive psychology of sustainable development, dealing with social and dispositional factors that enable satisfaction, quality of life and, even more, individual well-being. Thus, the environment should no longer be considered a constraint requiring efforts to adapt to it but more a potential source of positive emotions, as shown in works on restorative environments or place attachment (e.g., Lewicka 2011; Staats 2012). Because of the perceptions, attitudes and representations it arouses, the environment is a major source of influence on individuals' well-being and quality of life. But under what conditions? According to Uzzell and Moser (2006) “. . . a sustainable quality of life is only achieved when people interact with the envi-

C. Demarque $(\square)$

University of Toulouse 2, Le Mirail, France

e-mail: demarque@univ-tlse2.fr

F. Girandola

Aix-Marseille University, Aix-en-Provence, France e-mail: fabien.girandola@univ-amu.fr ronment in a respectful way, on one hand, and when that environment in turn is not impeding or threatening what the individual considers as their 'quality of life', on the other, this renders possible the capacity for the individual to satisfy their needs." (p. 3). Thus, individuals' environmental quality of life will depend on the evaluation of "people-environment congruity" through the subjective assessment of a combination of objective material factors of the daily environment. Fleury-Bahi et al. (2013) distinguished four dimensions that should be taken into account: physical and spatial environment, social context, environmental annoyances and local facilities/ services.

In line with this concept, we consider behavioral commitment a way to contribute to quality of life, by improving these objective indicators. In this sense, this chapter shows that commitment enables the introduction of new positive relations with the environment in a more or less direct way. Commitment produces cognitive (in terms of attitudes, emotions, representations) and behavioral effects likely to improve the perception of peopleenvironment congruity. To illustrate this idea, we provide a review of the commitment theory (e.g., Lokhorst et al. 2013) and of the effects of binding communication (Girandola and Joule 2012; Joule and Beauvois 2014; Joule et al. 2007b) on the adoption of pro-environmental behaviors such as waste sorting, recycling, non-activist behaviors in the public sphere and energy saving, likely 
to be positively perceived by the individual and contribute to quality of life.

First, the basis of commitment theory and its effects on the adoption of pro-environmental behaviors are described and the hypocrisy and self-fulfilling prophecies are presented. Then, we focus on the binding communication paradigm (i.e., theoretical and practical interest) and its objectives: to optimize awareness and information campaigns in order to favor behavioral adhesion. The effects of binding communication on behaviors and attitudes toward the environment are highlighted, including how these effects strengthen the positive characteristics of interactions between humans and the environment and, thereby, quality of life. Finally, action research based on binding communication in the field of promoting pro-environmental behaviors is reviewed. Uzzell and Moser's proposals (2006) are used to show that this paradigm has been applied at different levels of human-environment interactions, as defined by Moser (2003): (1) the private space level (household), (2) the proximal environment level, and (3) the public space level.

Finally, the current limitations of works on commitment, and especially the lack of precise measures of quality of life following research actions, are described. Most of the research presented in this chapter originated from institutional requests. Following logics that could be labeled as "top-down", the expected behavioral changes are rarely discussed with the populations concerned. We show the interest of doing such work beforehand. In particular, the role of social representations in binding communication and associated techniques (e.g., foot-in-the-door) is discussed, using studies showing that commitment strategies are more effective when they take into account some elements of social representations.

\subsection{Commitment Theory and Environmental Issues}

\subsubsection{The Commitment Theory}

Behavioral intention is the closest cognitive element for the effective fulfillment of a behavior (e.g., Ajzen and Fishbein 1980; Azjen 1991). Even so, the "intention to do something" does not usually predict the associated effective behavior (e.g., Webb and Sheeran 2006; Schultz and Kaiser 2012). For instance, Bickman (1972) showed that $95 \%$ of the participants in an experiment declared that they were willing to pick up litter from the ground. However, when they were observed in this situation, less than $2 \%$ actually did it. Likewise, information or awareness campaigns rarely lead to effective behaviors. They are necessary but not sufficient to provoke changes (e.g., Kaiser 2014; Schultz 2014; Schultz and Kaiser 2012; Steg and De Groot 2012; Steg et al. 2013).

Since Lewin (1947), it has been known that a behavioral change requires an act and/or a decision beforehand. In line with this idea, research on commitment reveals the influence techniques likely to generate a behavior change and their fallout at the cognitive and behavioral levels (e.g., Cialdini 2006; Kiesler 1971). The literature on behavioral changes in the field of sustainable development considers commitment an effective way to lead to the expected changes (e.g., McKenzie 2011; McKenzie-Mohr et al. 2012). In a meta-analysis focused on 19 studies carried out between 1976 and 2010, Lokhorst et al. (2013) confirmed this effectiveness.

Joule and Beauvois (1998) suggested bringing together the research on commitment and its behavioral and cognitive effects in the paradigm of free will compliance (Joule et al. 2007b). This concerns the study of techniques likely to lead someone to modify his/her behaviors voluntarily. Free will compliance highlights the essential role of preparatory acts in obtaining later commitments (Girandola 2003; Joule and Beauvois 2014; Girandola and Joule 2013). These generally consist of inexpensive acts (i.e., easy to perform) such as filling out a pro-environmental questionnaire (Freedman and Fraser 1966), giving time to a bystander in the street (Harris 1972), wearing a badge (Pliner et al. 1974), etc. These preparatory acts have a double function: on the one hand, they make individuals more sensitive to arguments or information diffused in the later persuasive 
message (Kiesler 1971); on the other hand, they increase the probability that these individuals will agree to perform consistent but more costly acts (e.g., foot-in-the-door, Burger 1999; Freedman and Fraser 1966), such as signing a petition or recycling waste (Dufourq-Brana et al. 2006). How can commitment be obtained? According to Joule and Beauvois (1998), it depends on:

1. Action visibility and importance. This category includes five factors: (a) the public nature of the action: an action carried out in public is more binding than one in private; (b) the irrevocability of the action: an irrevocable action is more binding than one that is not; (c) the repetition of the action: an action that is repeated is more binding than an action carried out once; (d) the consequences of the action: an action is more binding if it has important consequences; (e) the cost of the action: an action is more binding if it is costly in money, time, energy, etc.

2. The reasons for the action and the context of freedom. This category includes two factors: (a) the reasons imputed to the action may be external (i.e., situation or circumstances) or internal (i.e., personal values). External reasons reduce commitment: the greater the reward or the punishment, the more the action is justified. Thus, external reasons weaken the link between the individual and his/her action. On the contrary, internal reasons (e.g., "you really are a generous person") strengthen the bond between the individual and his/her actions; (b) the context in which the individual operates must give him/her the status of a "free" individual (e.g., "you are free to accept or refuse"). Commitment theorists consider freedom of choice the main commitment factor (e.g., Guéguen et al. 2013).

\subsubsection{Commitment and Pro-environmental Behaviors}

As mentioned by Dwyer et al. (1993), the 1960s in the United States marked the evolution of the 100-year-old conservation movement - fo- cused on the protection of wildlife and natural settings - toward an environmental movement, stressing the idea that environmental quality itself was threatened, partially because of human behavior. In fact, a notable series of environmental incidents occurred in the 1960s and 1970s (the Torrey Canyon and Amoco-Cadiz oil spills in 1967 and 1978, the Seveso dioxin cloud in 1976, the Three Mile Island nuclear accident in the USA), contributing to an ecological awareness. Several laws were also approved in the 1970s (the Clean Air Act, Clean Water Act, etc.), and a number of institutions were created; for instance, the Environmental Protection Agency (EPA) in the United States in 1970, the French Ministry of Environment in 1971, and the United Nations Conference on Human Environment held in Stockholm in 1972. In their review of 54 behavioral interventions to preserve the environment, Dwyer et al. (1993) observed the development in this period of research in the field of psychology, adapting the techniques of applied behavior analysis to environmentally relevant behaviors. They highlighted the relation between this socio-political context and the number of research studies in the environmental field, with a peak at the end of the 1970s and a steady decline through the 1980s. Their main conclusion was that antecedent conditions (i.e., activators or prompting strategies) using commitment, demonstrations and goal-setting strategies were effective in favoring pro-environmental behavior. They also observed that consequence conditions (i.e., feedback, rewards and penalties) were effective during the experiments. However, they underlined the methodological limitations of some of the studies (no comparison condition, few follow-up measures or little maintenance of the behavioral changes).

More recently, Lokhorst et al. (2013) conducted a meta-analysis on commitment in the environmental field, which confirmed its effectiveness overall. Research was mainly centered on recycling and energy conservation behaviors, through the use of two main techniques: the footin-the-door (Freedman and Fraser 1966) and the public pledge.

The foot-in-the-door technique consists of getting a person to agree to a modest request, in 
order to increase the likelihood that he/she will accept a larger request, that is, the target behavior. In the framework of commitment theory, we consider the first behavior a committing (or binding) preparatory act (cf. Joule and Beauvois 1998, 2014). The technique was first used in the environmental field by Arbuthnot et al. (1976/1977) whose research focused on recycling metal cans. The experimental design included three independent preparatory acts: a measure of the participants' knowledge about recycling, saving and sorting cans for 1 week, and writing a letter explaining the interest of the action 1 week after the cans were collected. The results notably showed a recycling rate of more than $80 \%$ in the condition combining the three preparatory acts, and also in the one combining saving cans and the letter. These results highlight the possible additive effects of the combined use of different preparatory acts, all the more so when they are consistent with the final request. This is in line with Kiesler's theoretical proposals (1971) about the continuous character of commitment. It should also be noted that the observed effects lasted 18 months after the experiment. The footin-the-door method has also been used to lead individuals to reduce their energy consumption (Katzev and Johnson 1983). Participants were asked to reduce their electricity consumption by $10 \%$. In the foot-in-the-door condition, this request was preceded by a low-cost preparatory act: answering a short questionnaire about energy conservation. During the 12 weeks of postexperimental measures, the highest number of participants who reduced their consumption was in the foot-in-the-door condition, by comparison with the 4-week experimental period. In another experiment on energy conservation, the authors showed that the foot-in-the-door was more effective over the long term than an incentivizing strategy, such as giving money to participants (Katzev and Johnson 1984).

Another commitment procedure, often found in the literature, is the public pledge, which was mainly used in studies to promote recycling behaviors. Pardini and Katzev (1983/1984) showed the effectiveness of this technique compared to a verbal commitment or a classic information procedure. Wang and Katzev (1990) observed that signing a commitment form, bearing the name of the participant's reference group, increased the average quantity of paper for recycling in a retirement home by almost $50 \%$, a new dynamic maintained during the 4-week postexperimental phase. For their part, Werner et al. (1995) showed that adding one's signature to a list of people interested in a recycling program was more effective in increasing commitment to this program than information (brochure) or persuasion (face-to-face interaction) procedures. These results are consistent with a series of previous observations (Katzev and Pardini 1987/1988; Wang and Katzev 1990; Katzev and Wang 1994). The results also revealed that the act of signing strengthened the participants' attitudes toward recycling at the same time. Pallak et al. (1980) observed the same kind of behavioral effects in the field of energy conservation.

\subsubsection{When Commitment Meets Dissonance: Hypocrisy and Self-Fulfilling Prophecies}

Experiments carried out on the hypocrisy paradigm suggest an interpretation in terms of cognitive dissonance (Festinger 1957; Fointiat et al. 2013a). It is the situation of hypocrisy itself that triggers the dissonance arousal, because it leads to a situation where the individuals becoming aware of the gap between their personal standards or their morally good self (i.e., "I see myself as sincere and honest") and their behavior (i.e., 'I' $m$ preaching a behavior I don't practice myself"). Dissonance, experienced as a state of mental stress or discomfort, motivates attempts to reduce it by changing behavior (e.g., Stone and Cooper 2001). From an operational point of view, hypocrisy, and thus dissonance, is induced through the combination of two successive steps. During step 1 ("commitment"), individuals make a normative speech (e.g., writing arguments) about a behavior (e.g., "Don't waste water"). Generally, this is a behavior that is not always performed by these individuals. During step 2 ("mindfulness"), previous transgressions are 
made prominent (e.g., earlier water waste), by asking these same individuals when, in the recent past, they did not act in accordance with the behavior they have just defended. This twostep strategy (i.e., commitment + mindfulness) arouses dissonance when the individual becomes aware that his/her earlier behaviors contradict his/her values and norms. A way of reducing dissonance is to perform pro-normative behaviors (i.e., saving water). Dickerson et al. (1992), for instance, carried out an experiment about water conservation in a hot dry Californian zone (Santa Cruz) near a pool. During step 1 (commitment), half the participants signed a flyer about water conservation, just before entering the locker room. The other half did not sign anything. During step 2 (mindfulness), half the participants filled in a questionnaire, supposedly about setting up a program against water waste. Actually, the questionnaire was used to make participants aware of their numerous wastes of water (i.e., recall of previous transgressions). The other half did not fill in this questionnaire (i.e., no recall of previous transgressions). Shortly afterwards, another experimenter measured the time spent under the shower by each participant. The results confirmed the hypotheses. Participants in the hypocrisy condition (steps $1+2$ ), took shorter showers (221 s on average), as a way of reducing their dissonance, than participants without recall of their transgressions (302 s on average). They also closed the tap more often during their shower (14 times on average) than in the control condition ( 7 times on average). Overall, hypocrisy can be considered an efficient technique for promoting pro-environmental and other pro-social behaviors (e.g., Fointiat et al. 2013b; Lopez et al. 2011; Stone and Fernandez 2008; Stone and Focella 2011).

Another paradigm deals with self-fulfilling prophecies. Asking someone if he/she will perform a behavior or not (i.e., "Ask yourself: Will I recycle?") increases the probability of it happening. Predicting a realization emphasizes the discrepancy between the normative beliefs linked to the behavior (e.g., I should recycle) and the behavioral transgressions (e.g., I don't recycle). By predicting his/her behavior, an individual be- comes aware, on the one hand, of what he/she does or does not do (previous behavior) and, on the other hand, of what he/she thinks he/she should do, that is, what is socially approved and morally good to do. Thus, the discrepancy between these two elements (i.e., past behavior and normative beliefs) is a source of dissonance (Spangenberg et al. 2003, 2012). The motivation to reduce the dissonance leads the individual to perform a behavior consistent with his/her prediction. For instance, Sprott et al. (1999) asked students to make a prediction about their future recycling behavior. As expected, those who made the prediction recycled more than those in a control group. Studies in this domain (Spangenberg et al. 2003) showed that a prediction request presented as a message for the general public, and consequently with no direct contact with anybody, increased the recycling rate by $12 \%$. In the same perspective, Spangenberg et al. (2003) reported several studies showing that self-fulfilling prophecies produced an effect on recycling behavior even in a situation of mass communication. One of these involved students of Washington State University and was divided into three phases: (1) a pre-experimental phase: before the campaign, (2) a campaign phase, during which an electronic board presenting the prediction request was installed, and (3) a postexperimental phase: after the campaign. The recycling behavior for each of these three phases was measured using containers. As expected, the recycling rate was higher during $(27.6 \%)$ and after $(28.2 \%)$ the prediction campaign than before $(15.8 \%)$. Sprott et al. (2003) manipulated the realization of a prediction (control vs. prediction) and the strength of normative beliefs (strong vs. weak). Their results confirmed that the effect of prophecies was greater when normative beliefs associated with the predicted behavior were strong. In another experiment, Rodrigues and Girandola (2014a, b) asked participants to predict their recycling behavior and then their normative beliefs and recycling habits were measured. Results showed that participants felt dissonance if, and only if, their recycling habit was weak and their normative beliefs were strong. After 30 years of research, studies show that self- 
fulfilling prophecies produce behavioral effects (Spangenberg and Greenwald 1999, 2001) with a moderate size effect (i.e., Cohen's $d=0.39$ or $r=0.19$ ).

\subsubsection{Toward a Binding Communication}

These results are very consistent. If, under certain conditions, persuasion influences attitudes, free will compliance procedures make it possible to obtain lasting behavioral effects in a context of freedom and favor commitment to a series of actions. However, despite their effectiveness for behavioral change, it should be noted that the great majority of these studies focused on the private sphere and at an individual level. Moreover, the dominant approaches of policy makers in this field are based on the idea that environmental issues can be solved by marginal changes in our way of life, an idea which is also widely held by the public. However, we agree with the following assessment: "The cumulative impact of large numbers of individuals making marginal improvements in their environmental impact will be a marginal collective improvement in environmental impact" (Thogersen and Crampton 2009). To go further and obtain deeper transformations of the physical and spatial environment, and thus favor quality of life more effectively, we consider the binding communication paradigm a promising approach. Lokhorst et al. (2013) showed that commitment was more effective when it was combined with other interventions. In this line, the binding communication paradigm suggests bringing together the fields of persuasion and commitment. It is presented in the following section along with empirical illustrations at different levels of spatiality.

The binding communication paradigm offers the possibility of working at the intersection of research conducted in the field of persuasive communication and those of commitment and free will compliance. The central assumption is that communication will be more effective when the exposure to a persuasive message is preceded by a preparatory act in a context of freedom (Girandola and Joule 2012). Thus, in the binding communication paradigm, as in the framework of classic persuasion (cf. Girandola 2003; Girandola and Joule 2012), pertinent questions remain: "What type of information should be conveyed?", "What are the best arguments to offer?", "What are the most appropriate channels of information?", to which we could add another important one: "Which preparatory actions must I obtain from those I want to rally?". A binding communication approach is distinguished from a more "traditional" one by taking into account this last question, and by conferring the status of "actor" on the target rather than that of a mere passive receiver (Girandola and Joule 2012, 2013; Joule et al. 2007; Michelik et al. 2012; Demarque et al. 2013a).

The interest of binding communication in the environmental field can be illustrated by a study that aimed to measure the effects of an electronic commitment on purchasing low-energy light bulbs by customers of a DIY store (Bernard et al. 2010). The commitment concerned installing a low-energy light bulb, instead of a classic one, at home. Overall, the results showed that customers who carried out the preparatory acts (i.e., clicks to replace a light bulb) bought significantly more low-energy light bulbs and expressed a more favorable attitude toward these bulbs 15 days later. Significantly more customers who signed an electronic commitment replaced a classic light bulb at home than those who did not sign the commitment. This experiment highlights the interest of leading individuals to preparatory actions in a binding communication situation. These make it easier to accept behaviors favoring energy conservation and, in addition, participate in improving household comfort.

This example shows the potential effectiveness of the binding communication paradigm. However, it is still situated at a strictly individual level and at the household level. In order to show how commitment and binding communication could improve quality of life in a significant way, the next section deals with the main research carried out with the binding communication paradigm at different levels of humanenvironment interactions. 


\subsection{Favoring Quality of Life Through Commitment and Binding Communication: Examples of Research at Three Different Space Levels}

People-environment relations involve problems of different natures according to the type and extent of the space concerned. These relations are located at several scales of spatial reference. Moser (2003) distinguished four levels, involving distinctive physical and social aspects (cf. Table 11.1). Here, another research study situated at level I is presented, which is noteworthy for its originality and innovative approach to quality of life. Furthermore, action research at levels II and III is described to show that commitment and binding communication should not be conceived only as techniques aiming at the adoption of individual behavior that would be an end in itself, but also as means to encourage collective dynamics. The importance of this dimension in leading to significant changes in individuals' life environment, a synonym of quality of life improvement, is discussed.

\subsubsection{At the Household Scale (Level I)}

The limitations of a focus on the household level were mentioned above. Therefore, it could seem paradoxical to begin this third section with the description of a research project centered on this level. However, we highlight its novelty and ambition to create a user community.

The Sensomi project was conducted from April 2011 to June 2013 in the ProvenceAlpes-Côte d'Azur (PACA) region in France. An ambitious part of the project was the development of a new type of device for obtaining commitment: an online cooperative video game, called Kwaan, specially created for the study (Demarque et al. 2013b). The first aim was to make individuals aware of the effects of their way of life on energy consumption, and then to foster effective energy-saving behaviors. Based on our understanding of quality of life, we began with the premise that it is necessary to recreate a positive bond between individuals and the physical reality of the terrestrial environment on which they depend, and for which energy is probably a more abstract issue. Thus, the project emphasized the idea of "hybridization" of reality and virtuality. In the framework of the commitment theory, an online game appeared a relevant way to favor commitment in a series of actions. In Kwaan, the players were collectively in charge of the life of an imaginary tree in an online community experience, based on an autonomous and collective learning process. Since their actual electricity consumption had an influence on the virtual tree, energy was no longer seen as an abstract aspect of reality. Moreover, the community dimension enabled

Table 11.1 Socio-spatial levels of analysis

\begin{tabular}{l|l|l|l}
\hline & Physical aspect of the environment & Social aspect of the environment & Type of space and control \\
\hline \multirow{2}{*}{ Level I } & Micro-environment & Individual & Private spaces \\
\cline { 2 - 4 } & Private space/housing & Family & Extensive control \\
\cline { 2 - 4 } & Work space & & \\
\hline \multirow{2}{*}{ Level II } & Proximal environments, neighborhood & Interindividual & Semi-public spaces \\
\cline { 3 - 4 } & & Community & Mediated control \\
\cline { 2 - 4 } & Open private spaces & Users, customers & Public spaces \\
\hline \multirow{2}{*}{ Level III } & Public environments & Inhabitants & Mediated control \\
\cline { 2 - 4 } & Cities, villages & Groups of individuals & Country, nation, planet \\
\hline \multirow{2}{*}{ Level IV } & Global environment & Society & Hypothetical control \\
\cline { 3 - 4 } & & Population & \\
\hline
\end{tabular}

From Moser 2003, p. 17 
one player to perceive what the other players were doing over time, which should reduce the feeling of being alone to act and commit the player in relation to the other players. One hundred and forty-eight psychology students at Aix-Marseille University participated in the study. In short, the results partially confirmed our hypotheses. They showed, on one hand, a marginally significant effect of the game on meter-reading behaviors in the free choice situation and, on the other hand, a significant positive effect of the game on the evolution of considering future consequences for the players who carried out at least $1 \mathrm{~m}$-reading behavior. However, these results should be considered with caution, considering the sample size and the weakness of the effects.

In their study, Fleury-Bahi et al. (2013) went beyond the private sphere and identified physical space as one of the dimensions of environmental quality of life. In the next section, we show the effectiveness of commitment and binding communication at higher socio-spatial levels on individual behaviors, which positively transform collective spaces and improve quality of life.

\subsubsection{At the Proximal Environment Scale (Level II)}

\subsubsection{In Schools}

In this section, a binding communication procedure conducted in 11 primary schools in the south of France, in the framework of the European project ALTENER (Joule 2004), is described. The aim of the project was to encourage 9- and 10 -year-old children, as well as their families, to adopt pro-environmental behaviors. The action involved 700 families and 28 teachers. During the school year, the teachers had to inform and convince their pupils of the importance of environmental protection and energy conservation (e.g., lessons, activities in the classroom), and lead them to perform preparatory actions (e.g., taking notes about their family's habits that could be changed without a loss of comfort, filling in a questionnaire with their parents about energy conservation at home, etc.). Each child was thus encouraged by his/her teacher to make an oral and written commitment and change his/her habits. Parents were also invited to make a commitment (e.g., leaving the car at home for short distances, replacing ordinary light bulbs by lowenergy ones, etc.).

The results showed that the majority of the children and parents (up to $100 \%$ in some classes) committed themselves to perform actions such as decreasing their energy consumption. Numerous studies have shown that a written commitment (or public pledge) usually results in the acceptance and performance of costly behaviors (Girandola and Roussiau 2003; Katzev and Wang 1994; Pallack et al. 1980; Wang and Katzev 1990). In our case, this campaign also led to improvements in some schools, such as replacing ordinary bulbs by low-energy bulbs or installing recycling bins. Some pupils wrote to their mayor, asking for the installation of timers for the lights in the school halls.

\subsubsection{Promoting Litter Recycling and Sorting at a Highway Rest Area}

In this study, the authors used binding communication procedures at a highway rest area in the south of France in order to encourage users to sort their trash (Blanchard and Joule 2006). In agreement with the highway operating company, two decisions were made: (1) to eliminate all isolated classic bins, and (2) to reduce the overall number of places where trash could be thrown away. This last decision led users to perform a preparatory action: to move with their trash. Once they had made this effort, they found three containers for sorting and a classic bin. They thus had a choice to make: sorting, using the special containers, or not sorting (putting everything in the classic bin). Results showed that the amount of sorted trash was multiplied by 3.5, compared to a control situation, without any deterioration in the cleanliness of the site. However, sorting 
was of lower quality. In order to improve this, a message was put on the bins: "I sort. For the planet, for my children and for my children's children". This message enabled users to identify their sorting at a high level of identification (Vallacher and Wegner 1985). It produced an improvement in the quality of sorting, which was controlled during visual checks of the bins. One of the novelties of the research was the absence of any direct contact with the users.

\subsubsection{At the Public Space Scale (Level III)}

\subsubsection{Protecting Beaches}

Joule et al. (2007a) tested the effectiveness of two communication procedures to lead beachgoers to keep beaches clean, notably by encouraging them not to throw their cigarette butts around or bury them in the sand. The first procedure consisted of exposing beachgoers to classic communication media (posters and brochures). The second procedure used binding communication: beachgoers were exposed to the same communication media, and were free to choose the commitment they wanted to make from a list of a dozen possible commitments, (e.g., not throw their cigarette butts in the sand). The research was conducted on a beach in Marseilles, which was divided into three zones comparable in surface area and in visitors. In the first zone, beachgoers were exposed to a classic communication procedure (i.e., persuasion). In the second zone, they were exposed to a binding communication procedure, and in the third zone, they were not exposed to any communication procedure (i.e., control zone). As expected, the observers detected, on a daily basis, 90 cigarette butts on average in the sand in the binding communication zone, 176 butts in the classic communication zone and 162 butts in the control zone. The beachgoers in the binding communication zone were observed without their knowledge, before and after their commitment: $77 \%$ put their cigarette butts in the sand before the intervention; $40 \%$ did so after the procedure.

\subsubsection{Mediterranean Coastline Conservation}

This action research was conducted on the Mediterranean coast along the Côte d'Azur (Joule et al. 2006). It concerned boaters (amateur sailors and professionals) and was carried out with an environmentalist association and about 50 "sea ambassadors" who met with boaters during the summer. The aim was to encourage amateur sailors to improve their behaviors and knowledge of sea conservation. The boaters were invited to perform freely different preparatory actions (accept a short interview about sea conservation, give their opinion about the most relevant advice to give to sailors, take a free booklet containing information and advice about sea conservation). Next, the ambassadors gave the sailors a commitment form that included a list of behaviors. They could freely commit to adopt one or several of these behaviors (e.g., do not anchor in the Posidonia meadow, use natural soaps). Finally, they could fly the association campaign flag on their boat, to serve as an example of environmental conservation: this action strengthened commitment because of its public character. More than 3000 boaters were solicited and almost all agreed to the interview, and then committed themselves to modify one or more behaviors by signing the commitment form. Based on questionnaires and direct observations, the results showed that the committed sailors had better knowledge and adopted more sea-friendly behaviors, in comparison with the non-committed ones.

\subsubsection{At a Town Scale}

Following a request from the environmental service of the PACA Region, a campaign was implemented to include two entire towns with all their inhabitants. It aimed to lead inhabitants to modify their behaviors regarding energy consumption (Joule 2004). Two towns of 8,000 inhabitants sharing common characteristics (i.e., size, social composition, climate conditions and environment) were selected in the south of France. Each 
of these two towns (A and B) used a different communication campaign.

In town $\mathrm{A}$, a classic communication campaign was used based on the usual media diffusion (posters, quiz, brochure with advice about energy conservation and a media plan of press articles in regional newspapers and municipal bulletins).

Binding communication was used in town B. This campaign used the same tools as in town A, as well as some independent actors (i.e., researchers trained in the commitment theory) and people living in the city who served as gobetweens (e.g., councilors, teachers, organizers, storekeepers, etc.) who encouraged actions favoring energy conservation. The actions were made public during an event day (exhibitions, plays, movies, debates, etc.) in order to get the inhabitants to make concrete commitments. They received a commitment form with a list of actions (e.g., walking rather than using the car for short trips, buying low-energy light bulbs). The inhabitants freely chose one or several actions to perform, and then signed the form. Each commitment was symbolized by a paper sun, cut out by school children and attached to a large net set up in the Town Hall square. Consequently, each inhabitant was able to follow the progression of the number of commitments. The results showed the effectiveness of binding communication: it produced a greater impact than the classic communication campaign. Average annual consumption per household increased less in comparison with the previous year in the town exposed to binding communication than in the town exposed to a classic communication campaign (6\% versus $14 \%)$. Overall, binding communication enabled the development of actions by the population and the public authorities. One of the interests of this project was the support of mediators in this procedure. The presence of the mediators probably maintained the innovative dynamics and the collective ambition developed during the project, which was aimed at improving the quality of life in an entire town.

\subsection{Perspectives and Conclusion}

The research described in this chapter outlines the different facets of the applications of the commitment theory in pro-environmental behaviors. At a time when pro-environmental communication campaigns are still searching for the right words, the commitment theory enables not only attitudinal changes but also behavioral ones. We have shown that this behavioral change can be on three different levels of space (private spaces, proximal environments and public spaces) and thus can potentially have a significant impact on the quality of life of the communities concerned. Although most of the studies focus on individual changes, we believe that this capacity to create a collective dynamic constitutes the future of research on commitment and binding communication.

In this perspective, the works about the link between social representations and commitment constitute a promising pathway. Eyssartier et al. (2009) suggested optimizing the effects of commitment by taking into account the social representations of a given object. A social representation is "a form of knowledge, socially produced and with a practical function, namely to contribute to the construction of a reality shared by a social group or entity" (Jodelet 1989, p. 36). From a structural point of view, social representations are regulated by central and peripheral systems (Abric 2001). The central system is fundamental to the social representation as it contains the more stable elements over time. It determines the meaning and the organization of the social representation. The peripheral system allows an adjustment to specific contexts and integration of the modulations. In the context of energy conservation, Souchet and Girandola (2013) showed that the study of social representations helps identify the preparatory actions likely to lead to the expected behaviors. These authors asked participants, chosen at random, if they would agree to answer a few questions about energy conservation (first preparatory action) and to write a short text in favor of conservation (second 
preparatory action). Each preparatory action activated either central elements of the representation (i.e., making energy savings, it's about conserving the environment) or peripheral elements (i.e., making energy savings, it's about using the car less). They were then asked to keep a diary for 2 weeks, to write down all the actions they carried out in favor of energy conservation, and to send their diary, at their expense, to the psychology department (final request). As expected, significantly more participants whose central elements were activated (e.g., environmental conservation) sent their diaries than those exposed to peripheral elements (e.g., using the car less). Other studies in the framework of sustainable development showed that the activation of central elements led to stronger effects in a situation of binding communication than the activation of peripheral elements (Zbinden et al. 2011). In addition to its usefulness for constructing persuasive arguments and enabling more effectiveness in terms of behavior (Eyssartier et al. 2009), the work on social representations provides a better understanding of the dynamic exchanges among the target group and, potentially, its expectations in terms of relations to the environment. For projects focusing on level III, a more systematic study of town representations could also prove very useful. Therefore, we suggest more in-depth work at the interface of these two research fields applied to sustainable development.

In conclusion, do the apparent behavioral changes automatically mean a better quality of life? Research on commitment mentioned above does not provide precise information about this aspect, which is one of its main limitations. Future projects need to integrate a more systematic use of environmental quality of life scales after the commitment procedures. Different tools are available depending on the aims and the level of spatiality on which the research focuses. For instance, at level I, administering the Residential Environmental Satisfaction Scale (RESS, Adriaanse 2007) before and after a project could evaluate the effect of a commitment procedure on residential quality of life. Another interesting tool, the Environmental Satisfaction Scale (Pelletier et al. 1996), is composed of two subscales, one measuring satisfaction with government policies, and the other measuring satisfaction with local environmental conditions. The latter subscale could be used for level II studies. Finally, we have already referred to Fleury-Bahi et al.'s scale (2013), which measures the four dimensions mentioned above.

Despite the absence of measures in the studies cited, some clues indicate that commitment and its consequences create satisfaction with the environment and an improvement in quality of life. This is the case of the research conducted in an entire town (Level III) in which the inhabitants were approached to commit themselves to proenvironmental behaviors. This commitment led to a reduction in wasting energy in comparison with a town without commitment procedures. After these first commitments, the project partners and the go-betweens decided to continue the actions. For instance, the town council took the initiative to fund training for heating installers. It also organized an Energy Trophy to reward the best initiatives for energy conservation. Therefore, even in the absence of precise measures, all these actions suggest that the commitment dynamic persists and constitutes a body of evidence in favor of improving environmental satisfaction and quality of life (cf. Uzzell and Moser 2006). Furthermore, we assume that individuals identify their action at a high level (e.g., "I' $m$ protecting the planet"), which is meaningful and easy to internalize (e.g., "It's natural for me to act like this"). Thus, individuals would finally be led to internalize and accept performing the action as a reflection of a personal value (Beauvois 2001). From this point of view, we can easily imagine a generalization of the initial action to other pro-environmental behaviors of the same kind: positive spillover effects take on great importance here.

This example of a town (level III) shows the value of involving go-betweens in the target population. This dimension seems very important to us and needs to be integrated more in future research. Effectively, most of the projects presented in this chapter originated from institutional demands. They took place in a global 
context where research is increasingly based on obtaining grants. In our examples, most of the research was funded by the PACA Region. In this framework, policy makers plan the expected behavioral changes beforehand and researchers have to develop experiments in order to achieve this goal. This raises the question of which entity defines what is "socially good" or what is a "socially acceptable" goal. In our view, there is a real necessity to co-develop or co-construct the definition of the intended goals with the populations involved beforehand. However, at present, research on commitment is generally based on approaches that we could qualify as top-down, as we try to answer an institutionally-defined goal (for instance, that of the European Union in the case of ALTENER or the PACA Region for the Sensomi project), usually made without prior consultation. In the future, it seems important to develop more participatory approaches when defining objectives, as is the case in other social science projects.

\section{References}

Abric, J.-C. (2001). L'approche structurale des représentations sociales: développements récents. Psychologie et Société, 4, 81-103.

Adriaanse, C. C. M. (2007). Measuring residential satisfaction: A residential environmental satisfaction scale (RESS). Journal of Housing and the Built Environment, 22, 287-304.

Ajzen, I. (1991). The theory of planned behavior. Organizational Behavior and Human Decision Processes, 50, 179-211.

Ajzen, I., \& Fishbein, M. (1980). Understanding attitudes and predicting social behavior. Englewood Cliffs: Prentice-Hall.

Arbuthnot, J., Tedeschi, R., Wayner, M., Turner, J., Kressel, S., \& Rush, R. (1976/1977). The induction of sustained recycling behavior through the foot-in-thedoor technique. Journal of Environmental Systems, 6, 355-368.

Beauvois, J. L. (2001). Rationalization and internalization: The role of internal explanations in attitude change and the generalization of an obligation. Swiss Journal of Psychology, 60, 215-230.

Bernard, F., Halimi-Falkowicz, S., \& Courbet, D. (2010). Expérimentation et communication environnementale: la communication engageante et instituante. In D. Courbet (Ed.), Objectiver l'humain ? Communication et expérimentation (Vol. 2, pp. 71-113). Paris: Lavoisier.
Bickman, L. (1972). Environmental attitudes and actions. Journal of Social Psychology, 87(2), 323-324.

Blanchard, G., \& Joule, R. V. (2006). La communication engageante au service du tri des déchets sur les aires d'autoroutes: une expérience-pilote dans le Sud de la France. Actes du $2^{\text {ème }}$ Colloque International Ecocitoyenneté : des idées aux actes favorables à l'environnement, Marseille, France, 9-10 November.

Burger, J. M. (1999). The foot-in-the-door compliance procedure: A multiple-process analysis and review. Personality and Social Psychology Review, 3(4), 303325.

Cialdini, R. B. (2006). Influence: The psychology of persuasion. New York: HarperBusiness.

Demarque, C., Apostolidis, T., \& Joule, R. V. (2013a). Consideration of future consequences and proenvironmental decision making in the context of persuasion and binding commitment. Journal of Environmental Psychology, 36, 214-220.

Demarque, C., Charles, M., Bourguignon, D., \& Lo Monaco, G. (2013b, October). Influence of a virtual environment on an energy conservation behaviour: the case of a cooperative online game. Paper presented at the International Congress of Environmental Psychology, Barcelona, Spain.

Dickerson, C., Thibodeau, R., Aronson, E., \& Miller, D. (1992). Using cognitive dissonance to encourage water conservation. Journal of Applied Social Psychology, 22, 841-854.

Dufourcq-Brana, M., Pascual, A., \& Guéguen, N. (2006). Déclaration de liberté et pied-dans-la-porte. Revue Internationale de Psychologie Sociale, 19, 173-187.

Dwyer, W. O., Leeming, F. C., Cobern, M. K., Porter, B. E., \& Jackson, J. M. (1993). Critical review of behavioral interventions to preserve the environment: Research since 1980. Environment and Behavior, 25, 275-321.

Eyssartier, C., Guimelli, C., \& Joule, R. V. (2009). Représentations sociales et engagement. In P. Rateau \& P. Moliner (Eds.), Représentations sociales et processus cognitifs (pp. 151-163). Rennes: PUR.

Festinger, L. (1957). A theory of cognitive dissonance. Stanford: Stanford University Press.

Fleury-Bahi, G., Marcouyeux, A., Préau, M., \& AnnabiAttia, T. (2013). Development and validation of an environmental quality of life scale: Study of a French sample. Social Indicators Research, 113(3), 903-913.

Fointiat, V., Girandola, F., \& Gosling, P. (2013a). La dissonance cognitive. Quand les actes changent les idées. Paris: Armand Colin.

Fointiat, V., Priolo, D., Saint-Bauzel, R., \& Milhabet, I. (2013b). Justifier nos transgressions pour réduire notre hypocrisie? Hypocrisie induite et identification des transgressions. Revue Internationale de Psychologie Sociale, 4, 49-78.

Freedman, J. L., \& Fraser, S. C. (1966). Compliance without pressure: The foot-in-the-door technique. Journal of Personality and Social Psychology, 4, 195-202.

Girandola, F. (2003). Psychologie de l'engagement et de la persuasion. Besançon: PUFC. 
Girandola, F., \& Joule, R. V. (2012). La communication engageante: aspects théoriques, résultats et perspectives. L'Année Psychologique, 112(1), 115-143.

Girandola, F., \& Joule, R. V. (2013). Attitude, changement d'attitude et comportement. In L. Bègue \& O. Desrichard (Eds.), Traité de psychologie sociale. La science des interactions humaines (pp. 221-248). Brussels: De Boeck.

Girandola, F., \& Roussiau, N. (2003). L'engagement comme source de modifications à long terme. Cahiers Internationaux de Psychologie Sociale, 57, 83-101.

Guéguen, N., Joule, R. V., Halimi-Falkowicz, S., Pascual, A., Fischer-Lokou, J., \& Dufourcq-Brana, M. (2013). I'm free but I'll comply with your request: Generalization and multidimensional effects of the "evoking freedom" technique. Journal of Applied Social Psychology, 43, 116-137.

Harris, M. B. (1972). The effects of performing one altruistic act on the likelihood of performing another. Journal of Social Psychology, 88, 65-73.

Jodelet, D. (1989). Les représentations sociales. Paris: Presses Universitaires de France.

Joule, R. V. (2004). What is the role of energy-education in changing habits? European congress "Energy education: roles, actors and tools. European experiences", Brussels Belgium.

Joule, R. V., \& Beauvois, J.-L. (1998). La soumission librement consentie. Paris: Presses Universitaires de France.

Joule, R. V., \& Beauvois, J.-L. (2014). Petit traité de manipulation à l'usage des honnêtes gens (3rd edition). Grenoble: Presses Universitaires de Grenoble.

Joule, R. V., Masclef, C., \& Jarmasson, J. (2006). Communication engageante et préservation de la méditerranée: comment promouvoir de nouveaux comportements de la part des plaisanciers ? Actes du $2^{\text {ème }}$ Colloque International Ecocitoyenneté: des idées aux actes favorables à l'environnement, Marseille, France, 9-10 November.

Joule, R. V., Bernard, F., Laganne, J., \& Girandola, F. (2007a). Promote cleanness of beaches: Communication and committing communication. 10th European Congress of Psychology, 3-6th July, Prague, Czech Republic.

Joule, R. V., Girandola, F., \& Bernard, F. (2007b). How can people be induced to willingly change their behavior? The path from persuasive communication to binding communication. Social \& Personality Psychology Compass, 1, 493-505.

Kaiser, F. G. (2014). Using cutting-edge psychology to advance environmental conservation. European Psychologist, 19(2), 81-83.

Katzev, R., \& Johnson, T. R. (1983). A socialpsychological analysis of residential electricity consumption: The impact of minimal justification techniques. Journal of Economic Psychology, 3, 267-284.

Katzev, R., \& Johnson, T. R. (1984). The use of posted feedback to promote recycling. Psychological Reports, $71,259-264$.
Katzev, R., \& Pardini, A. (1987/1988). The comparative effectiveness of reward and commitment in motivating community recycling. Journal of Environmental Systems, 17, 93-113.

Katzev, R., \& Wang, T. (1994). Can commitment change behavior? A case study of environmental actions. Journal of Social Behavior and Personality, 9, 13-26.

Kiesler, C. A. (1971). The psychology of commitment. New York: Academic.

Lewicka, M. (2011). Place attachment: How far have we come in the last 40 years? Journal of Environmental Psychology, 31(3), 207-230.

Lewin, K. (1947). Group decision and social change. In E. Swanson, T. M. Newcomb, \& E. L. Hartley (Eds.), Readings in social psychology (pp. 197-211). New York: Holt.

Lokhorst, A. M., Werner, C., Staats, H., van Dijk, E., \& Gale, J. L. (2013). Commitment and behavior change: A meta-analysis and critical review of commitmentmaking strategies in environmental research. Environment and Behavior, 45(1), 3-34.

Lopez, A., Lassarre, D., \& Rateau, P. (2011). Dissonance et engagement. Comparaison de deux voies d'intervention visant à réduire les ressources énergétiques au sein d'une collectivité territoriale. Pratiques Psychologiques, 17, 263-284.

McKenzie-Mohr, D. (2011). Fostering sustainable behavior: An introduction to community-based social marketing. Gabriola Island: New Society Publishers.

McKenzie-Mohr, D., Lee, N. R., Schultz, P. W., \& Kotler, P. (2012). Social marketing to protect the environment: What works. Washington, DC: Sage.

Michelik, F., Girandola, F., Joule, R. V., Zbinden, A., \& Souchet, L. (2012). Effects of the binding communication paradigm on attitudes. Swiss Journal of Psychology, 71(4), 227-235.

Moser, G. (2003). Questionner, analyser et améliorer les relations à l'environnement. In G. Moser \& K. Weiss (Eds.), Espaces de vie: Aspects de la relation hommeenvironnement (pp. 11-42). Paris: Armand Colin.

Pallak, M. S., Cook, D. A., \& Sullivan, J. J. (1980). Commitment and energy conservation. In L. Bickman (Ed.), Applied social psychology annual (pp. 235253). Beverly Hills: Sage.

Pardini, A., \& Katzev, R. (1983/1984). The effect of strength of commitment on newspaper recycling. Journal of Environmental Systems, 13, 245-254.

Pelletier, L. G., Legault, L. R., \& Tuson, K. M. (1996). The environmental satisfaction scale: A measure of satisfaction with local environmental conditions and government environmental policies. Environment and Behavior, 28, 5-26.

Pliner, P., Hart, H., Kohl, J., \& Saari, D. (1974). Compliance without pressure: Some further data on the footin-the-door technique. Journal of Experimental Social Psychology, 10, 17-22.

Rodrigues, L., \& Girandola, F. (2014a). Auto-prophéties: une application en faveur du recyclage des déchets. International Congress of Applied Psychology, Paris, France, 8-13 July. 
Rodrigues, L., \& Girandola, F. (2014b). Auto-prophéties : effets du libre-choix et du degré de croyances normatives. $10^{\text {ème }}$ Colloque International de Psychologie Sociale en Langue Française, Institut de Psychologie, Paris, France, 27-30 August.

Schultz, P. W. (2014). Strategies for promoting proenvironmental behavior: Lots of tools but few instructions. European Psychologist, 19(2), 107-117.

Schultz, P. W., \& Kaiser, F. G. (2012). Promoting proenvironmental behavior. In S. D. Clayton (Ed.), The Oxford handbook of environmental and conservation psychology (pp. 556-580). New York: Oxford University Press.

Souchet, L., \& Girandola, F. (2013). Double foot-in-thedoor, social representations and environment: Application for energy savings. Journal of Applied Social Psychology, 43(2), 306-315.

Spangenberg, E. R., \& Greenwald, A. G. (1999). Social influence by requesting self prophecy. Journal of Consumer Psychology, 8(1), 61-89. doi:10.1207/ s15327663jcp0801_03.

Spangenberg, E. R., \& Greenwald, A. G. (2001). Selfprophecy as a behavior modification technique in the United States. In W. Wosinska, R. B. Cialdini, D. W. Barret, \& J. Reykowski (Eds.), The practice of social influence in multiple cultures (pp. 51-62). Mahawah: Lawrence Erlbaum.

Spangenberg, E. R., Sprott, D. E., Grohmann, B., \& Smith, R. J. (2003). Mass-communicated prediction requests: Practical application and cognitive dissonance explanation for self-prophecy. Journal of Marketing, 67, 4762. doi:10.1509/jmkg.67.3.47.18659.

Spangenberg, E. R., Sprott, D. E., Knuff, D. C., Smith, R. J., Obermiller, C., \& Greenwald, A. G. (2012). Process evidence for the question-behavior effect: Influencing socially normative behaviors. Social Influence, 7(3), 211-228.

Sprott, D. E., Spangenberg, E. R., \& Perkins, A. W. (1999). Two more self-prophecy experiments. In L. Scott \& E. J. Arnould (Eds.), Advances in consumer research (Vol. 25, pp. 621-626). Provo: Association for Consumer Research.

Sprott, D. E., Spangenberg, E. R., \& Fisher, R. J. (2003). The importance of normative beliefs to the selfprophecy effect. Journal of Applied Psychology, 88, 423-431. doi:10.1037/0021-9010.88.3.423.

Staats, H. (2012). Restorative environments. In S. Clayton (Ed.), The Oxford handbook of environmental and conservation psychology (pp. 445-458). New York: Oxford University Press.

Steg, L., \& de Groot, J. I. M. (2012). Environmental values. In S. Clayton (Ed.), The Oxford handbook of environmental and conservation psychology (pp. 8192). New York: Oxford University Press.
Steg, L., Van den Berg, A. E., \& De Groot, J. I. M. (2013). Environmental psychology: An introduction. Chichester: BPS Blackwell.

Stone, J., \& Cooper, J. (2001). A self-standards model of cognitive dissonance. Journal of Experimental Social Psychology, 37, 228-243.

Stone, J., \& Fernandez, N. C. (2008). To practice what we preach: The use of hypocrisy and cognitive dissonance to motivate behavior change. Social and Personality Compass, 2, 1024-1051.

Stone, J., \& Focella, E. (2011). Hypocrisy, dissonance and the self-regulation processes that improve health. Self and Identity, 10, 295-303.

Thøgersen, J., \& Crompton, T. (2009). Simple and painless? The limitations of spillover in environmental campaigning. Journal of Consumer Policy, 32, 141163.

Uzzell, D., \& Moser, G. (2006). Environment and quality of life. European Review of Applied Psychology, 56(1), $1-4$.

Vallacher, R. R., \& Wegner, D. M. (1985). A theory of action identification. Hillsdale: Lawrence Erlbaum Associates.

Wang, T. H., \& Katzev, R. D. (1990). Group commitment and resource conservation: Two field experiments on promoting recycling. Journal of Applied Social Psychology, 20, 265-275.

Webb, T. L., \& Sheeran, P. (2006). Do changing behavioral intentions engender behavior change? A metaanalysis of the experimental evidence. Psychological Bulletin, 132, 249-268.

Weiss, K., \& Girandola, F. (2009). Qualité de l'environnement et comportements écocitoyens. In J. Lecomte (Ed.), Introduction à la psychologie positive (pp. 251-263). Paris: Dunod.

Weiss, K., \& Girandola, F. (2010a). Les enjeux de la psychologie face au développement durable. In K. Weiss \& F. Girandola (Eds.), Psychologie et développement durable (pp. 9-19). Paris: Editions InPress.

Weiss, K., \& Girandola, F. (2010b). Pour une psychologie positive du développement durable: vers de nouveaux enjeux et développements. In K. Weiss \& F. Girandola (Eds.), Psychologie et développement durable (pp. 277-282). Paris: Editions InPress.

Werner, C. M., Turner, J., Shipman, K., Twitchell, F. S., Dickson, B. D., Bruchke, G. V., \& von Bismarck, W. B. (1995). Commitment, behavior, and attitude change: An analysis of voluntary recycling. Journal of Environmental Psychology, 15, 197-208.

Zbinden, A., Souchet, L., Girandola, F., \& Bourg, G. (2011). Communication engageante et représentations sociales: une application en faveur de la protection de l'environnement et du recyclage. Pratiques Psychologiques, 17, 285-299. 